\title{
Pengembangan Usaha Mikro Melalui Pemanfaatan Buah Semangka Di Desa Henda Kecamatan Jabiren Raya, Kabupaten Pulang Pisau Kalimantan Tengah
}

\author{
Alexandra Hukom ${ }^{1 *}$, Chen Chen Kristanto Laga, Welly, Yulitha Naumi, Kristiyanus Riyan, Nova \\ Elisa K, Maria Adeltrudis Mei De, Zidane Maulis Marantizen Basuki, Minati Feratika, Maju \\ Siagian, Niko Samboja, Upik Lestari Gea, M. Fachtur Reza, Zhafron Adani Kautsar, Kamelia, \\ Anita Maulina
}

Fakultas Ekonomi dan Bisnis, Universitas Palangka Raya

*) e-mail: alexandra.hukom @feb.upr.ac.id

\begin{abstract}
Abstrak
Desa Henda adalah salah satu desa yang terletak di kecamatan Jabiren Raya Kabupaten Pulang Pisau. Hasil identifikasi potensi dan permasalah desa diketahui bahwa desa Henda memiliki potensi yang belum dimanfaatkan oleh masyarakat yaitu pada sektor perkebunan semangka dan unit usaha mikro kecil tidak berkembang karena belum memiliki produk jual yang bervariasi. Tujuan dari kegiatan pengabdian masyarakat ini adalah pemanfaatan hasil perkebunan semangka yang ada di Desa Henda sebagai suatu produk baru yang dikembangkan oleh usaha mikro kecil Desa Henda. Pembuatan produk baru yang didesain adalah selai buah semangka. Pada masa pandemi, proses pelaksaan pengabdian masyarakat di Desa Henda dilakukan melalui pembuatan video dan buku panduan yang disebarkan ke sasaran yaitu ibu-ibu kelompok PKK (Pemberdayaan Kesejahteraan Keluarga) yang juga merupakan petani semangka. Dengan adanya kegiatan pengabdian masyarakat melalui program Kuliah Kerja Nyata Tematik (KKNT) ini, masyarakat desa merasa terbantu karena menjadi sumber pendapatan baru bagi masyarakat terutama bagi ibu-ibu PKK petani Desa Henda.
\end{abstract}

Kata kunci: selai semangka, usaha mikro kecil

\section{Abstract}

Henda Village is one of the villages located in the Jabiren Raya sub-district, Pulang Pisau Regency. The results of the identification of village potentials and problems show that Henda village has untapped potential by the community, namely the watermelon plantation sector and the micro-small business unit is not developing because it does not have a variety of selling products. The purpose of this community service activity is to utilize the results of watermelon plantations in Henda Village as a new product developed by small micro businesses in Henda Village. The manufacture of a new product designed is watermelon jam. During the pandemic, the process of implementing community service in Henda Village was carried out through making videos and guidebooks which were distributed to the target group of PKK (Family Welfare Empowerment) women who are also watermelon farmers. With this community service activity through the Thematic Real Work Lecture (KKNT) program, the village community feels helped because it is a new source of income for the community, especially for PKK farmers in Henda Village.

Key word: watermelon jam, micro small business

\section{Pendahuluan}

Desa Henda adalah salah satu desa yang terletak di kecamatan Jabiren Raya, Kabupaten Pulang Pisau, Kalimantan Tengah. Secara monografi desa Henda terbagi dalam 3 RT (Rukun Tetangga). Desa Henda berada di Daerah Aliran Sungai (DAS) kahayan dan sebagian berada di sisi jalur jalan lintas trans Kalimantan ${ }^{1}$. Pada umumnya mata pencaharian masyarakat desa Henda adalah petani dengan jumlah penduduk 654 jiwa/159 kepala keluarga yang terdiri dari 347 jiwa laki-laki dan 307 jiwa perempuan $^{2}$. Berdasarkan hasil observasi terdapat beberapa permasalah yang dialami oleh desa salah satunya adalah tidak berkembangnya Usaha Mikro Kecil (UMK) di

\footnotetext{
${ }^{1}$ Badan Restorasi Gambut. 2018. Profil Desa Peduli Gambut. BRG: Desa Henda Kecamatan Jabiren Raya Kabupaten Pulang Pisau.

${ }^{2}$ Badan Pusat Statistik Kabupaten Pulang Pisau. 2020.

Kecamatan Jabiren Raya Dalam Angka 2020. BPS

Pulang Pisau: Pulang Pisau
}

desa. Masyarakat kurang atau belum kreatif dalam bidang ekonomi menjadi salah satu faktor tidak berkembangnya UMK di desa Henda, padahal desa Henda memiliki beberapa sektor yang berpotensi untuk dimanfaatkan sebagai UMK. Salah satu potensi unggulan yang dimiliki oleh desa Henda selain pada sektor pertanian adalah perkebunan semangka. Desa Henda terkenal akan penghasil buah semangkanya diantara desa-desa lain yang ada di kecamatan Jabiren Raya.

Tanaman semangka (Citrullus vulgaris) adalah tanaman yang berasal dari Afrika $^{3}$. Semangka (Citrullus vulgaris) merupakan tanaman dari famili Cucurbitaceae (labulabuan) yang bersifat semusim ${ }^{4}$. Dalam buah

\footnotetext{
${ }^{3}$ Mochd, B. K. 2006. Bertanam Semangka. Penebar Swadaya: Jakarta.

${ }^{4}$ Kusumastuti U.D, Sukarsa dan P. Widodo. 2017. Keanekaragaman Kultivar Semangka [Citrullus Lanatus (Thunb.) Matsum. dan Nakai] di Sentra Semangka
} 
semangka diketahui banyak terdapat kandungan zat-zat yang sangat berguna bagi kesehatan tubuh manusia. Kandungan dari zatzat tersebut dapat bermanfaat untuk melindungi jantung, memperlancar pengeluaran urine, dan menjaga kesehatan kulit. Fungsi buah semangka tidak hanya dapat menghilangkan dahaga tetapi juga sebagai antioksidan yang baik. Buah semangka dapat diandalkan sebagai penetral radikal bebas dan mengurangi kerusakan sel dalam tubuh karena memiliki kadar antioksidan yang tinggi ${ }^{5}$. Buah semangka mengandung banyak air (sekitar 92 persen) dan mengandung likopen sebesar 48,8 persen 6 , buah semangka juga mengandung asam amino sitrulin, kalium, air, vitamin $\mathrm{C}$, vitamin $\mathrm{A}$ (karotenoid), dan vitamin $\mathrm{K}^{7}$.

Berdasarkan hasil observasi beserta fakta-fakta diatas maka kelompok $59 \mathrm{KKN}-$ Tematik Reguler Periode II Universitas Palangka Raya Tahun 2021 membuat program kerja pengabdian masyarakat dengan melakukan inovasi pembuatan produk bernilai jual dari buah semangka yaitu selai semangka. Selai semangka dipilih sebagai produk inovasi pada kegiatan pengabdian karena proses pembuatan tidak memerlukan waktu lama, alat yang digunakan pasti dimiliki oleh rumah tangga masyarakat desa Henda, dan produk ini dapat tahan lama setelah diproduksi (maksimal satu bulan), jika memang ingin dipasarkan. Selain itu, pengolahan selai semangka memiliki biaya rendah yang terjangkau oleh petani semangka di Desa Henda. Dengan inovasi pengembangan produk selai semangka diharapkan dapat membantu masyarakat Desa Henda terutama para petani semangka memperoleh penghasilan tambahan untuk memenuhi kebutuhan dan meningkatkan taraf hidup masyarakat.

\section{Metode Pelaksanaan Kegiatan}

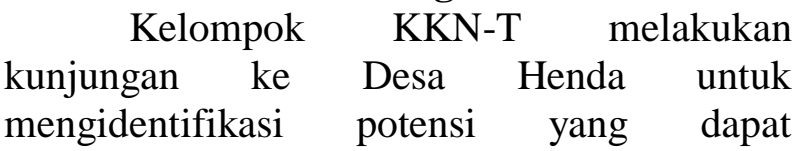
dikembangkan serta permasalah-permasalahan yang sedang dihadapi masyarakat desa. Hasil dari identifikasi potensi dan permasalahan tersebut akan digunakan sebagai dasar dari menentukan program kerja yang akan disusun dan dilaksanakan di desa Henda.

Nusawungu Cilacap. J. Scripta Biologica, 4 (1), pp. 15 19

${ }^{5}$ Rochmatika, L. D., Kusumastuti, H., Setyaningrum, G. D. \& Muslihah, N. I. 2012. Analisis Kadar Antioksidan Pada Masker Wajah Berbahan Dasar Lapisan Putih Kulit Semangka (Citrullus vulgaris schrad). Seminar Nasional Penelitian, Pendidikan dan Penerapan MIPA.

6 Tadmor, Y., King, S., Levi, A., Davis, A., Meir A., Wasserman B., Hirschberg, J., Lewinsohn, E. 2005.

Comparative Fruit Colouration in Watermelon and Tomato. Food Rest Int, 38(8-9),pp. 837-841.
Pelaksanaan program kerja UMK "Pengolahan Pasca Panen Buah Semangka Sebagai Produk Selai" di Desa Henda Kecamatan Jabiren Raya Kabupaten Pulang Pisau.

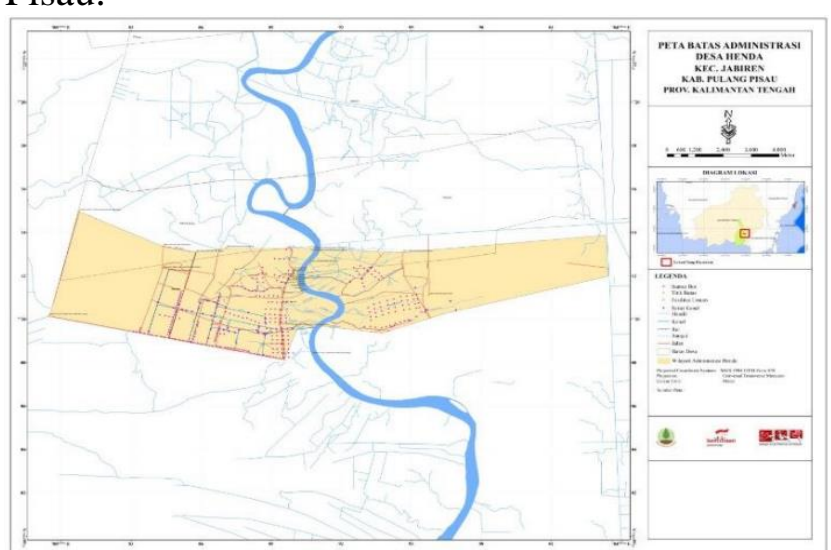

Gambar 1. Peta Lokasi Desa Henda (Badan Restorasi Gambut, 2018)

Setelah hasil identifikasi potensi dan permasalahan desa didapatkan dan program kerja disusun, selanjutnya yang dilakukan adalah melaksanakan program kerja. Pendekatan pengabdian kepada masyarakat dilakukan dengan metode Video Based Learning. Istilah video based learning digunakan dalam pembelajaran untuk mendesain pengetahuan atau keterampilan yang diperoleh dengan diajarkan melalui video. Media video adalah salah satu jenis media audio-visual dan dapat mencerminkan suatu objek yang bergerak bersama dengan suara alami atau yang sesuai. Video menyajikan informasi, proses menggambarkan, menjelaskan konsep yang rumit, mengelola keterampilan, meringkas atau memperjanjang waktu, dan membuat perubahan pada sikap ${ }^{8}$. Penggunaan Metode Video Based Learning dilaksanakan karena tidak memungkinkan diadakannya pelatihan atau sosialisasi pembuatan selai semangka secara langsung akibat pandemi Covid-19 dan adanya PPKM (Pemberlakuan Pembatasan Kegiatan Masyarakat) sehingga tidak memungkinkan untuk melaksankan kegiatan program kerja secara luring di desa. Tahap pelaksanaan kegiatan terdiri dari:

1. Uji coba pembuatan selai semangka

2. Pembuatan desain label kemasan

3. Produksi selai semangka sekaligus pembuatan video tutorial pembuatan selai semangka

\footnotetext{
${ }^{7}$ Sulung, Neila, Drin PP. 2015. Buah Semangka (Citrullus vulgaris) terhadap Tekanan Darah pada Lansia dengan Hipertensi. Jurnal INJEC, 2(2), pp.268273.

${ }^{8}$ Melinda, V. A., Degeng, N. S., \& Kuswandi, D. 2018. Pengembangan Media Video Pembelajaran IPS Berbasis Virtual Field Trip (Vft) Pada Kelas V SDNU Kratonkencong. JINOTEP (Jurnal Inovasi Dan Teknologi Pembelajaran) Kajian Dan Riset Dalam Teknologi Pembelajaran, 3(2) pp.158-164
} 
4. Pembuatan buku panduan program kerja

5. Penyerahan sampel produk selai semangka dan buku panduan program kerja
Adapun bagan kerangka pelaksanaan kegiatan pengabdian masyarakat kelompok KKNT digambarkan pada Gambar 2.

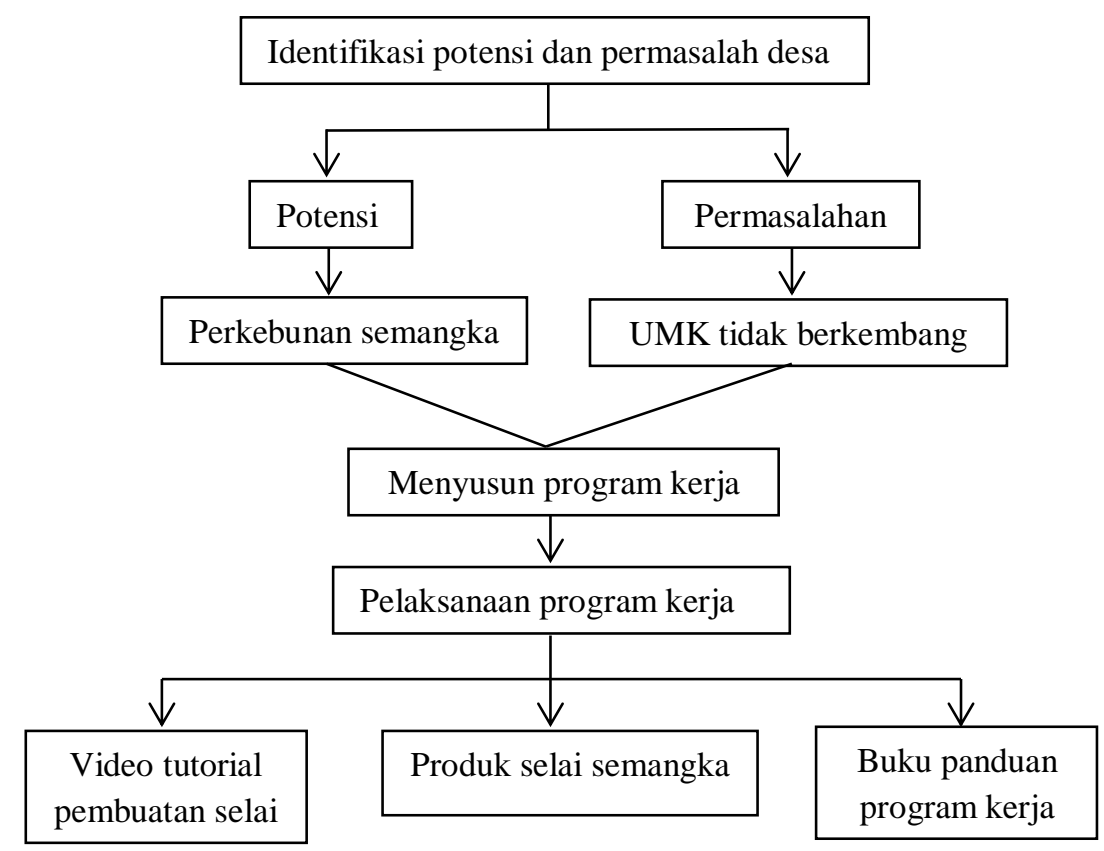

Gambar 2. Diagram Alir Metode Pelaksanaan Program Kerja

\section{Hasil dan Pembahasan}

Hasil dari identifikasi potensi dan permasalahan desa yang ada di desa Henda adalah diketahui bahwa UMK di desa Henda tidak berkembang, kurangnya kesadaran masyarakat serta minimnya informasi serta pengetahuan untuk mengelola dan mengolah sektor-sektor yang berpotensi di desa menyebabkan tidak adanya perkembangan pada sektor UMK di desa Henda. Perkebunan semangka adalah salah satu potensi yang belum dimanfaatkan secara optimal oleh masyarakat di desa Henda. Berdasarkan permasalahan diatas kelompok KKN-T menyusun program kerja UMK dengan melakukan inovasi pembuatan produk bernilai jual dari buah semangka yaitu selai semangka.

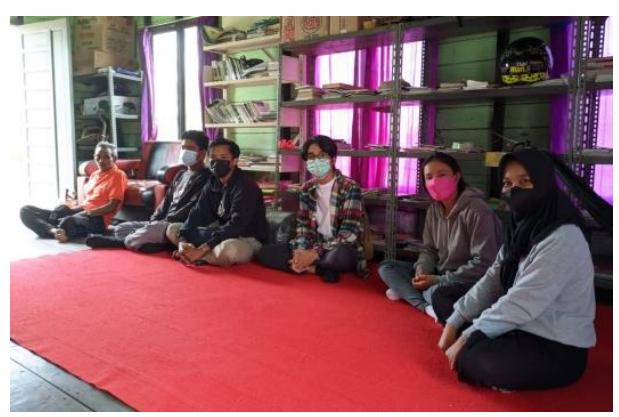

Gambar 3. Survei Kelompok KKNT ke Desa Henda
Uji coba pembuatan selai semangka dilakukan dengan tujuan memastikan resep, bahan-bahan, takaran bahan dan proses pembuatannya sudah baik dan benar agr menghasilkan produk selai semangka yang berkualitas dan bernilai jual.

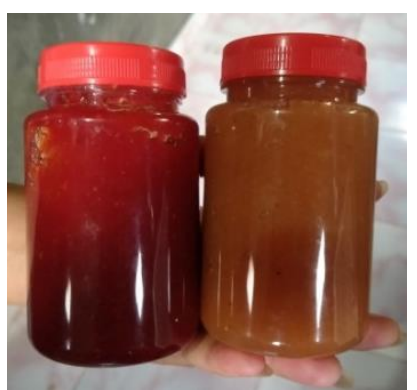

Gambar 4. Hasil Uji Coba Pembuatan Selai Semangka

Pembuatan desain label kemasan dilakukan di posko KKN-T dengan melibatkan anggota kelompok yang ditugaskan untuk membuat desain kemasan. Terdapat tiga desain yang dihasilkan, kemudian dilakukan penilain oleh anggota kelompok lainnya untuk menentukan satu desain yang akan diimplementasikan pada kemasan. Label kemasan sendiri memuat informasi mengenai nama produk beserta logo produk, komposisi bahan yang digunakan, serta manfaat dan kandungan yang terdapat dalam selai semangka. 


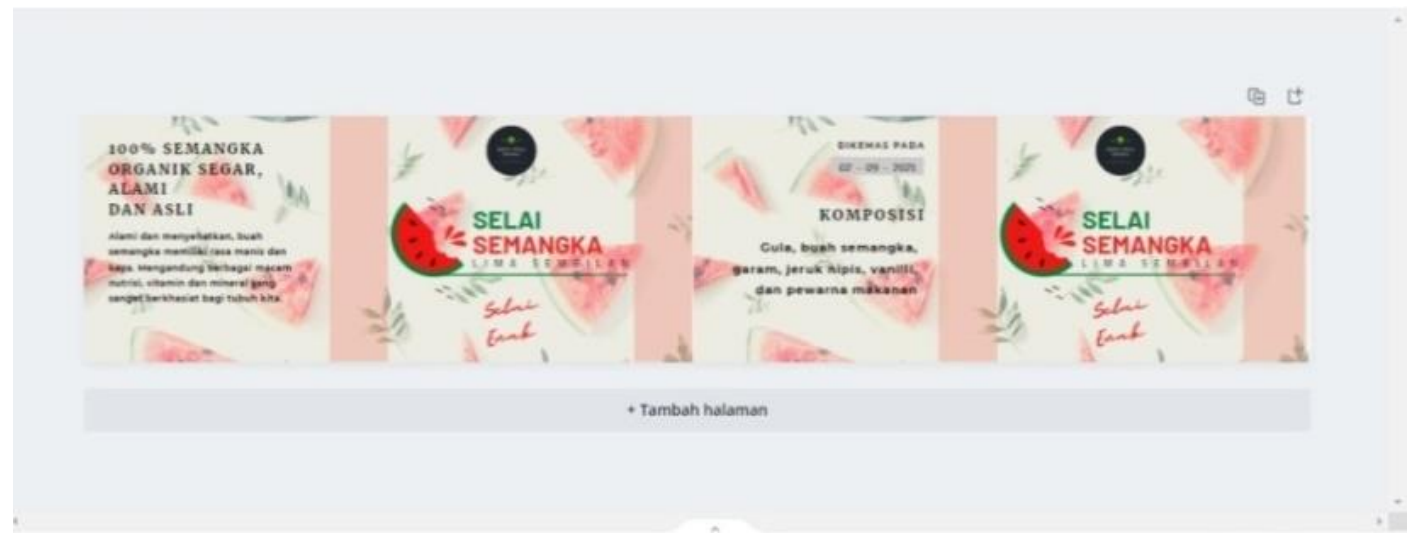

Gambar 5. Desain Kemasan Selai Semangka

Produksi selai semangka sekaligus pembutan video edukasi cara pembuatan selai semangka melibatkan seluruh anggota kelompok KKN-T. Video ini kemudian diputar pada saat kunjungan luring ke Desa Henda dan juga di upload di youtube. Link youtube dari kegiatan pembuatan selai ini adalah https://youtu.be/fiCaCOoNeC4 . Melalui media social link ini disebarkan kepada masyarakat Desa Henda terutama kepada ibu-ibu PKK dan petani semangka di Desa Henda.

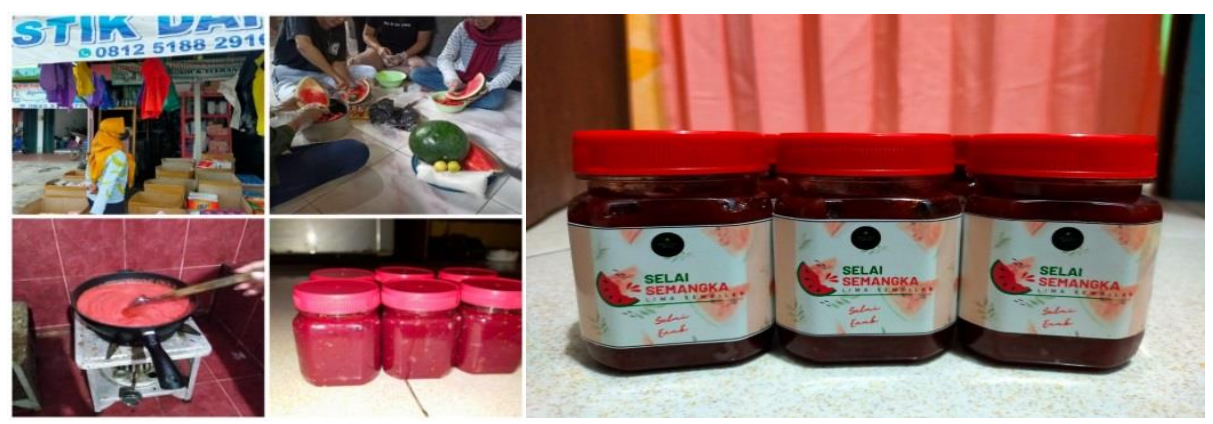

Gambar 6. Proses pembuatan selai semangka dan pemasangan label kemasan

Selain pembuatan video edukasi tentang cara pembuatan selai semangka, alternatif lain untuk menggantikan pelatihan ataupun sosialisasi pembuatan selai semangka adalah pembuatan buku panduan program kerja yang berjudul "Pengolahan Pasca Panen Buah Semangka sebagai Produk Selai”. Buku panduan program kerja ini diharapkan dapat membantu Ibu PKK (Pemberdayaan Kesejahteraan Keluarga), Kelompok Tani dan juga masyarakat desa Henda yang ingin mengembangkan UMK di desa Henda. Buku panduan program kerja ini berisi mengenai informasi terkait buah semangka yaitu meliputi kandungan serta manfaat buah semangka bagi kesehatan, terdapat informasi mengenai langkah-langkah cara pengolahan buah semangka menjadi selai dan tips agar selai dapat bertahan lama tanpa menggunakan bahan pengawet makanan.

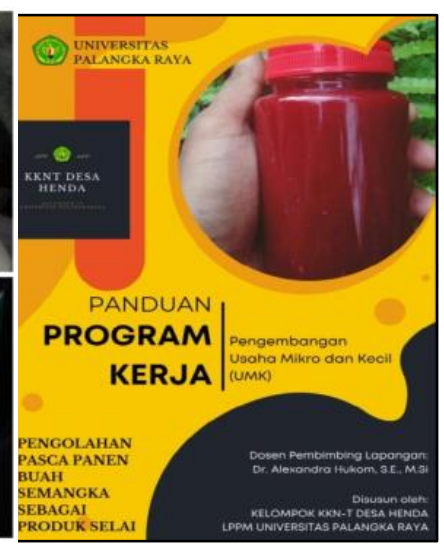

Gambar 7. Pembuatan Buku Panduan Program Kerja
Penyerahan sampel produk selai semangka beserta buku panduan program kerja dengan judul "Pengolahan Pasca Panen Buah Semangka sebagai Produk Selai” dilakukan diakhir masa kegiatan KKN-T sebagai puncak pengerjaan program kerja. Penyerahan sampel produk selai semangka beserta buku panduan program kerja bertempat di Aula Sanggar Seni 
Desa Henda dengan dihadiri pihak desa yang diwakilkan oleh Bapa Siel selaku sekretaris desa.

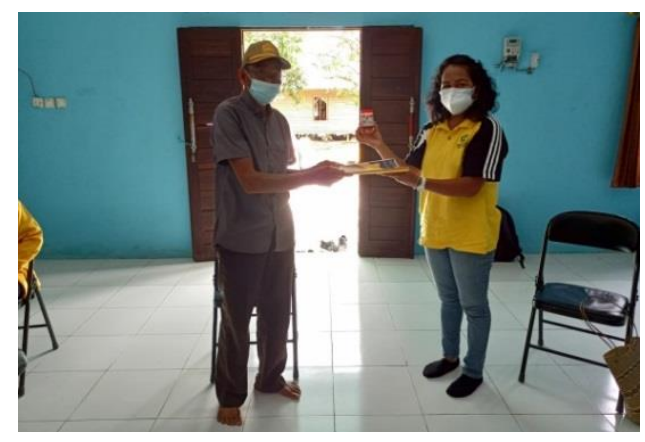

Gambar 8. Penyerahan Sampel Produk Selai Semangka dan Buku Panduan Program Kerja

\section{Kesimpulan}

Desa Henda merupakan salah satu Desa di Kabupaten Pulang Pisau yang memiliki potensi perkebunan semangka. Selama ini semangka hanya dijual langsung oleh petani, tidak ada inovasi pengolahan semangka menjadi produk baru. Dengan adanya kegiatan pengabdian masyarakat melalui program KKNT ini, masyarakat desa merasa terbantu dengan informasi cara pengolahan buah semangka menjadi selai semangka. Kegiatan ini dilakukan pada masa Pandemi Covid 19 sehingga proses pembuatan selai semangka dibuat dalam bentuk video yang dapat diakses langsung masyarakat desa dan buku panduan yang dibagikan kepada petani semangka, ibuibu PKK maupun masyarakat desa. Dengan adanya inovasi produk buah semangka menjadi selai semangka diharapkan para petani semangka memperoleh pendapatan tambahan dalam memenuhi kebutuhan hidupnya dan meningkatkan kesejahteraan keluarga. 